PAPER

\title{
What is it to practise good medical ethics? A Muslim's perspective
}

\author{
G I Serour
}

\section{Correspondence to}

Professor G I Serour,

International Islamic Center for Population Studies and

Research, Al Azhar University, 40 Talaat Harb Street, City

Center, Cairo, Egypt;

giserour1@link.net

Received 27 August 2014

Revised 23 September 2014

Accepted 24 September 2014

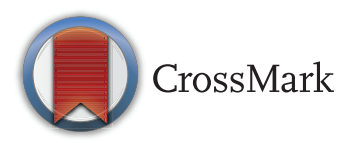

To cite: Serour Gl. J Med Ethics 2015;41:121-124.

\section{ABSTRACT}

Good medical ethics should aim at ensuring that all human beings enjoy the highest attainable standard of health. With the development of medical technology and health services, it became necessary to expand the four basic principles of medical ethics and link them to human rights. Despite the claim of the universality of those ethical principles, their perception and application in healthcare services are inevitably influenced by the religious background of the societies in which those services are provided. This paper highlights the methodology and principles employed by Muslim jurists in deriving rulings in the field of medical ethics, and it explains how ethical principles are interpreted through the lens of Islamic theory. The author explains how, as a Muslim obstetrician-gynaecologist with a special interest in medical ethics, including international consideration of reproductive ethics issues, he attempts to 'practise good medical ethics' by applying internationally accepted ethical principles in various healthcare contexts, in ways that are consistent with Islamic principles, and he identifies the evidence supporting his approach. He argues that healthcare providers have a right to respect for their conscientious convictions regarding both undertaking and not undertaking the delivery of lawful procedures. However, he also argues that withholding evidence-based medical services based on the conscientious objection of the healthcare provider is unethical as patients have the right to be referred to services providing such treatment.

Health as defined in the WHO constitution is a state of complete physical, mental and social wellbeing and not merely the absence of disease or infirmity. The highest attainable standard of health is a fundamental right of every human being without distinction of race, religion, political belief, economic or social condition. Good medical ethics aims to ensure that all human beings enjoy the highest attainable standard of health without distinction on any basis. Huge disparities exist in healthcare services and their quality between the North and the South and between the rich and the poor, which violates the basic ethical principles of justice, equity and equality: "of all the forms of inequality, injustice in healthcare is the most shocking and inhumane" (Martin Luther King, Jr.). Despite the claim of the universality of the four prima facie ethical principles, their perception and application must be influenced by the social, cultural, legislative and religious backgrounds of different societies. In this paper I shall discuss some global developments in international and intercultural medical ethics, Islamic perspectives of medical ethics, the application of good medical ethics in some specific instances of healthcare provision, and conscientious objection to treatment.

\section{DEVELOPMENTS IN INTERNATIONAL AND INTERCULTURAL MEDICAL ETHICS}

In any learned profession, specific standards of conduct which guide the behaviour of its members are established in codes of ethics. ${ }^{1}$ To underpin such codes in medical ethics, Beauchamp and Childress in the late seventies proposed the widely adopted four prima facie ethical principles of beneficence, non-maleficence, justice and autonomy. ${ }^{2}$ The International Association of Bioethics defined bioethics as the study of ethical, social, legal, philosophical and other related issues arising in healthcare and biological sciences. ${ }^{3}$ Because of rapid advances in scientific knowledge and technology and their impact on the quality of health services provided, it became necessary to enormously expand the four ethical principles of the seventies. In 2005, the Universal Declaration on Bioethics and Human Rights was developed by UNESCO and adopted by United Nations Member States. Articles 3-17 of the Declaration outlined many other ethical principles in addition to the four previously established and linked all to human rights. These principles included human dignity and human rights, benefit and harm, autonomy and individual responsibility, consent, special concern for persons without the capacity to consent, respect for human vulnerability and personal integrity, privacy and confidentiality, equality, justice and equity, non-discrimination and non-stigmatisation, respect for cultural diversity and pluralism, solidarity and cooperation, social responsibility and health, sharing of benefits, protecting future generations, and protection of the environment, biosphere and biodiversity. ${ }^{4}$ Bioethics has been defined by $\mathrm{WHO}$ as a field of ethical enquiry that examines ethical issues and dilemmas arising from health, healthcare and research involving humans, ${ }^{5}$ thus highlighting the importance of health research ethics.

Societies differ in their practice of medical ethics, differences that are most often based on cultural, religious, social, bioethical and legal norms. Such diversity is strikingly apparent in assisted reproductive technology (ART) within member states of the European Union. ${ }^{6}$ Progressive Scandinavian countries such as Norway and Sweden have enacted restrictive ART legislation against both third-party donation and surrogacy. On the other hand, Spain, 
a traditionally Catholic country with a large Muslim population, is now the European centre for cross-border ART because it allows third-party donation. ${ }^{7}$ Likewise, third-party ART is provided in Lebanon to both Muslims and Christians, but not in neighbouring Egypt or Italy. ${ }^{8}$

Even in secular societies, principles, values and beliefs are corporately held by communities and transmitted as part of their culture. When some principles are given absolute value in an authoritarian community, prohibition follows, as in some Catholic societies. We should then be aware of the risk to women's and newborns' health when laws on human reproduction are modelled on the values of theologians rather than on evidence-based science and respect for and protection of the human rights of women. ${ }^{9}$ However, when general principles are given a high but presumptive value, and moral emphasis rests less on religious authority and more on reasoned appeal to conscience, the way is open for moral reasoning to establish greater tolerance of individual moral decision-making. However, such diversity highlights the need for ethicists and practitioners to understand and be tolerant of the complex interactions between culture, religion, local morality and legislation when addressing these medical practices through the lens of global bioethics.

\section{ISLAMIC PERSPECTIVES ON MEDICAL ETHICS}

Science and religion have been inter-related since the beginning of human history. As we celebrate the journal's 40th anniversary, we cannot deny that the past four decades have witnessed the secularisation of bioethics and a decline in religious influence in the field of ethics, which has become dominated by philosophical, social and legal concepts. ${ }^{10}$ However, in many parts of the world and particularly in the Middle East, religion is still widely meaningful and influences many behaviours, practices and policies. This also applies to many observant followers of various religions living around the globe. Medical ethics are based on the moral, religious and philosophical ideals and principles of the society in which they are practised. It is therefore not surprising to find that what is ethical in one society may not be ethical in another society. With globalisation, healthcare providers (HCPs) and patients alike are moving around to different parts of the world, and it is not uncommon for HCPs to provide medical services to patients with ethical values different from their own. Providing an enlightened insight into Islamic medical ethics will help clinicians, Muslims and non-Muslims, be more knowledgeable when communicating with their Muslim patients. Such informed counselling is important to ensure better concordance with treatment and provision of a quality healthcare service which is culturally sensitive.

\section{Deriving ethical principles}

Few publications discuss the methodology and principles employed by Muslim jurists in deriving rulings in the field of medical ethics. Bioethical principles have been interpreted through the lens of Islamic ethical theory, identifying the evidence using an approach frequently employed among Muslims. ${ }^{11}{ }^{12}$ In Islam there is no central authority as in the Catholic religion and truly ethical conduct consists of personal searching for relevant values that lead to an ethically inspired decision. Muslims need to distinguish between medical ethics and humanitarian consideration on the one hand and religious teachings and national laws on the other.

The primary and most authentic source of rulings and principles in Islam is the Holy Quran. Muslims believe that the Quran is the word of God revealed to the Prophet Mohammed, praise be unto him (PBUH), via the archangel Gabriel. The revelation of the Quran to the Prophet Mohammed (PBUH) began in 610 $\mathrm{AD}$ and continued over 23 years. Under changing circumstances, the rulings given in the Quran may have differed. Thus the context for the ruling has to be taken into consideration in such cases. ${ }^{13}$ During the reign of Abu Bakr, the first Islamic ruler after the Prophet (PBUH), the Quran was collected and kept in one place. Uthman, the third Islamic ruler, made a number of copies of the Quran which were distributed to different parts of the Muslim world. Therefore, there is one version of the Quran which preserves its authenticity throughout time. The Quran is not simply a book of rituals. It is a book of guidance and has its own method of persuasion and dissuasion, instilling the desire for reward and the fear of punishment. It presents rules of conduct in a language and context that appeal to the emotions, conscience, mind and belief in God. ${ }^{13}$

The set of instructions which regulates the everyday activities of life to be adhered to by an observant Muslim is called Shariaa. The primary sources of Shariaa in a chronological order are: the Holy Quran; the Sunna and Hadith, which are the authentic traditions and sayings of Prophet Mohammed (PBUH) as collected by specialists in Hadith; and Igmaa, which is the unanimous opinions of Islamic scholars or Aaimma, and analogy (Kias) for Sunni Muslims or intellect (Aql) for Shiite Muslims, which is the intelligent reasoning used to rule on events not mentioned by the Quran and Sunna by matching against similar or equivalent events previously ruled on. In matters not discussed by primary sources of Shariaa, observant Muslims would refer to secondary sources of Shariaa which include: Istihsan, which is the choice of one of several lawful options, the views of the Prophet's companions, current lawful customs, public welfare and the rulings of previous divine religions if not contradicted by the primary sources of Shariaa. Shariaa is not rigid and adapts to new emerging situations according to human needs. Islam is a religion of Yusr (ease) and not Usr (hardship) and is directed to the benefit of humanity. ${ }^{14} 15$

The broad principles of Islamic jurisprudence are permissibility (Ibaha), unless prohibited by a text, no harm and no harassment, and necessity permits the prohibited and the choice of the lesser harm. Islam has affirmed the importance of marriage, family formation, procreation, purity of lineage, and the preservation and protection of the environment and future generations. $^{15} 16$

Islamic attitudes to the four prima facie ethical principles first developed in 1979 were discussed in great detail by Serour in $1994,{ }^{11}$ and recently by Mustafa in $2014 .^{12}$ These and almost all the ethical principles in the UNESCO's Declaration of Bioethics and Human Rights are supported in the primary sources of Shariaa. ${ }^{11} 15$

Recently there has been justifiable confusion about who speaks for Islam. This explains the huge differences between what Islam says and what some Muslims say and do. Islam differs from some other religions in that there is no central doctrinal authority in Islam after the Prophet Mohammed (PBUH). No one can claim exclusive ownership of the truth about Islam. Eminent religious scholars in the early period of Islam mostly concluded their opinions on various issues arising in everyday life by saying 'and God knows better'. Islamic clergy only have as much moral authority as the trust people put in their knowledge and honesty. ${ }^{13}$ Islamic religious scholars often disagree with each other and their differences are considered a mercy (as it accommodates for differences) for Muslims. One eminent scholar said his views are correct but may be wrong and the other's views are wrong but they may be right! Ultimately it is 
the people who have to make responsible decisions, which today we call autonomy. It is implausible to expect that the statements of religious scholars over the past several hundred years should be followed today by all 1 billion 200 million Muslims around the globe. The Holy Quran, and when needed the authentic Hadith of Prophet Mohammed (PBUH), remain the unchallenged supreme authority in Islam.

\section{GOOD MEDICAL ETHICS REGARDING SOME HEALTHCARE ISSUES}

\section{Vulnerable groups}

Women, adolescents and children tend to be vulnerable because of social, cultural and economic circumstances and need protection. However, these groups have often been dominated by the paternalism of their HCPs and the power of their male partners. ${ }^{1}$ So that quality healthcare services based on ethical principles can be provided, women should have the freedom to decide whether, when and how often to bear children. Women have the right to be informed, to provide/withold consent, and to have access to safe, effective, affordable and acceptable methods of fertility regulation of their choice. Obtaining women's free informed consent or dissent in healthcare services should be a continuing process with the right to withdraw consent at any time. Adolescents and children have the right to have access to information and high quality youth-friendly health services which ensure privacy and protect the confidentiality of all information disclosed. Children should be protected from all harmful practices such as female genital mutilation (FGM) including its medicalisation, as well as all forms of violence and abuse. ${ }^{17-19}$ The provision of ethically acceptable healthcare service to pregnant women should take ethical obligations to both the pregnant woman and the fetus into consideration with neither automatically receiving priority. ${ }^{20}$ Justice implies that all be treated with equal standards irrespective of socio-economic status and that patients have equal access to healthcare without discrimination or coercion. ${ }^{1}$ When resources are limited, the provision of life-saving healthcare services and tackling public health problems takes precedence over the provision of expensive health technology services such as ART. ${ }^{16}{ }^{21}$

\section{Assisted reproductive technology}

Because it is expensive, ART, an established treatment for both female and male infertility, is not a priority for many healthcare systems in high or low income countries. This highlights is a striking tension between utility and equity and justice. When resources are limited and basic health services are lacking, implementation of ART would be unjust because it would deprive a major section of the population of life-saving and basic health services. ${ }^{22}$ However, justice and social responsibility demand that people should not be denied advanced healthcare services on the basis of their social background. A mechanism has to be found to provide advanced medical services for the needy who cannot afford them. ${ }^{1}$ The challenging tasks will be to simplify ART so that it becomes affordable in low and middle income countries, with the cost but not the quality reduced, and special attention given to minimising complications such as ovarian hyperstimulation syndrome, multiple pregnancy (MP) and prematurity. ${ }^{21}$ Some developed countries such as Belgium have a single embryo transfer policy to minimise MP complications. Access to ART is dependent not on the wealth of the country but on the distribution of wealth, as well as social and geopolitical factors. ${ }^{23}$ Thus ART practices vary markedly in different parts of the world depending on religious, cultural, economic and legislative influences. ${ }^{16} 2124$
This has resulted in a growing market for cross-border ART, so-called reproductive tourism, which enables the rich to cross borders to access various types of ART not available in their home countries. Such practices involve discrimination against and exploitation of needy and disadvantaged women. ${ }^{1}$

For Muslims, if ART is indicated as necessary for a married couple, it is permitted and even encouraged as it preserves humankind. ${ }^{15}{ }^{24}$ The Sunni Muslim guidelines emphasise the necessity of maintaining purity of lineage. Thus sperm donation, egg donation or embryo donations are not permitted. Most Sunni scholars would not approve of surrogacy. However, the Shiaa guidelines have opened the door to third-party donation, via a fatwa from Ayatollah Ali Hussein Khameini in 1999. Egg and sperm donation and surrogacy have gained acceptance among Shiaa Muslims. ${ }^{8}{ }^{24}$ Multifetal pregnancy reduction, sex selection for medical and social reasons if it does not involve discrimination against either sex, and pregnancy in postmenopausal women (PPM) using the patient's cryopreserved oocytes are permitted. ${ }^{22}{ }^{25}$ Sex selection is of particular ethical concern when it is driven by value differences ascribed to each sex or that arise from pervasive gender stereotypes. ${ }^{26}$

It is now possible to have PPM using one's own cryopreserved embryos, oocytes and autografted cryopreserved ovarian tissue. However, PPM is discouraged in light of the special care necessary for the management of pregnancy in a woman beyond normal childbearing age, and children's need for parents likely to survive at least into their mid-adolescence. Nevertheless, PPM may be permissible in exceptional cases, if justified there are pressing circumstances, there are minimal risks for mother and child, and the parents have the capacity to discharge childrearing responsibilities. ${ }^{22} 27$ This is supported by the verses in the Holy Quran which oblige parents to feed, cloth and care for their newborn in a seemly manner, although no one should be charged beyond their capacity or made to suffer because of their child. ${ }^{28}$ In support of this argument is the recent removal and placing for adoption of an Italian female child born as a result of cross-border ART to a father aged 70 and a mother aged 57. The Italian courts have said that the decision to remove the child was not due to her parent's age but was solely motivated by a concern for her welfare because of poor parenting. ${ }^{29}$

\section{Safe motherhood}

Marriage, pregnancy and childbirth, and family formation are very important for Islamic society. Islam values motherhood highly as pregnancy and child birth are responsible for the continuation of the human species on earth. Islam supports safe motherhood and the care of pregnant and lactating women as well as child spacing, as outlined in several verses in its primary sources. ${ }^{111} 13141528$

\section{Family planning}

Islamic Shariaa has called for child spacing and family planning. While the Holy Quran was being revealed, the Prophet (PBUH) learned that his companions (Sahaba) were practising al-azl (coitus interruptus) but did not prohibit it. Thus al-azl for temporary contraception is permissible (ja'iz) and lawful. The majority (jumhour) of jurists agree with that al-azl is permitted. ${ }^{15}$ Imam Al-Ghazali allowed al-azl, with the wife's consent, for health and economic reasons and even to preserve a woman's figure and beauty for the continued enjoyment of her life with her husband. Temporary contraceptives as such pills, IUDs, injectables or other methods are allowed. Permanent contraception is permitted if pregnancy and child birth endanger the life of the mother. A thorough review of the Quran 
reveals no text (nuss) prohibiting the prevention or planning of pregnancy, which actually seem to be permitted by several traditions of the Prophet. ${ }^{15}$

\section{Other medical practices}

The same methodology is also applicable to derive rulings and ethical guidelines on other medical practices evolving as a result of the application of modern technology, including organ transplantation, genetic testing, stem cell research, embryo research, cosmetic surgery, FGM and euthanasia. Ethical guidelines are issued by scholars and jurists on such practices, not mentioned in the primary sources of Shariaa, by referring to the principles of Islamic jurisprudence and the purposes of the law (Maqasid al Shariaa) which promotes the preservation of religion (din), life (nafs), progeny (nasl), intellect (Aql) and wealth (mal).

\section{CONSCIENTIOUS OBJECTION}

Globalisation and the continuous movement of HCPs from one country to another have created situations and dilemmas not previously encountered in traditional medical practice. It is quite common for patients and their HCPs to have different religious and ethical perspectives concerning healthcare services.

The primary ethical commitment of HCPs is to serve their patients' health and well-being by offering the highest quality and safety of care. HCPs have a duty to inform their patients of all medically indicated options for their care, including those in which they themselves would decline to participate. They should not allow their advice to be influenced by personal beliefs that differ from professionally accepted medical evidence and/or guidelines. If in an emergency, a patient's physical or mental health, or indeed life, can be preserved only by a procedure to which the HCP usually objects, and the HCP cannot find a non-objecting HCP to replace them, then he/she must give priority to the patient's life, health and well-being by performing or participating in the indicated procedure. ${ }^{1}$

HCPs who are postgraduate students or in training have a duty to inform their teachers and/or supervisors of their conscientious objection in a timely fashion, to ensure that alternative arrangements for the appropriate care of their patients can be made. ${ }^{30}$ They cannot decline training in procedures performed for medically indicated purposes to which they do not object even though the same procedures can be used for medical indications to which they do object.

HCPs have a right to respect for their conscientious convictions regarding both undertaking and not undertaking the delivery of lawful procedures, and to not suffer discrimination on the basis of their convictions. Their right to respect for their choices regarding medical procedures and care in which they participate also requires that they respect patient choices regarding medically indicated options for their care. ${ }^{30}$

HCPs may sometimes be subject to violence or pressure because they provide evidence-based treatment opposed by some groups or authorities, for instance HCPs have been threatened and attacked for providing pregnancy terminations and recently for administering poliomyelitis vaccination in Nigeria, Pakistan and Afghanistan. ${ }^{31}$ It is a professional and societal obligation to advocate for the rights and security of each HCP to practise his/her profession within the law and with protection from interference or intimidation from any source, governmental or non-governmental. This has been emphasised by the Islamic Advisory Group and other religious leaders. ${ }^{32}$
Competing interests None.

Provenance and peer review Commissioned; internally peer reviewed.

\section{REFERENCES}

1 Serour GI. Ethical issues in human reproduction: Islamic perspectives. Gynecol Endocrinol 2013;29(11):949-52.

2 Beauchamp TL, Childress JF. Principles of biomedical ethics. 7th edn. New York: Oxford University Press, 2013.

3 Bioethics International. http://bioethicsinternational.org/

4 The United Nations Educational, Scientific and Cultural Organization (UNESCO). Universal Declaration on Bioethics and Human Rights. Paris: UNESCO, 2005.

5 The World Health Organization (WHO). Research ethics committees: basic concepts for capacity-building. Geneva: WHO, 2009.

6 Jones HW Jr, Cohen J. IFFS surveillance 07. Fertil Steril 2007;88:1478-9.

7 Matorras R. Reproductive exile versus reproductive tourism. Hum Reprod 2005;20:3571.

8 Inhorn MC, Patrizio P, Serour GI .Third-party reproductive assistance around the Mediterranean: comparing Sunni Egypt, Catholic Italy and multisectarian Lebanon. RBM Online 2010;21(7):848-53.

9 Zegers-Hochschild F, Dickens BM, Dughman-Manzur S. Human rights to in vitro fertilization. Int J Gynaecol Obstet 2014;18(1):27-31.

10 Serour GI. Ethical considerations of assisted reproductive technologies: a Middle Eastern perspective. Middle East Fertil Soc J 2000;5:13-18.

11 Serour GI. Islam and the four principles. In: Gillon R, ed. Principles of health care ethics. London: John Wiley \& Sons, 1994:75-91.

12 Mustafa Y. Islam and the four principles of medical ethics. J Med Ethics 2014;40:479-83.

13 Fathalla MF, ed. What does Qur'an say about women? 2014. http://alazhar-iicpsr. org/data/uploads/books/Reproductive\%20Health\%20Books/EN/what-does-thequran-say-about-women-book.pdf

14 Holy Quran, Sura Al-Bakara 2:185.

$15 \mathrm{Gad}$ El Hak AGE, Serour Gl, eds. Some gynecological problems in the context of Islam. Cairo: IICPSR, Al-Azhar University, 2000

16 Serour GI. Attitudes and cultural perspectives on infertility and its alleviation in the Middle East area. In: Vayena E, Rowe PJ, Griffin PD, eds. Current practices and controversies in assisted reproduction. Geneva, Switzerland: WHO, 2002: 41-9.

17 Serour GI. The issue of reinfibulation. Int JGO 2010;109:93-6.

18 Serour GI. Medicalization of female genital mutilation/cutting. AJU 2013;19: 145-9.

19 Children in Islam: Their care, upbringing and protection. Al Azhar University and UNICEF 2005. http://www.unicef.org/egypt/Egy-homepage-Childreninislamengsum(1).pdf

20 Chervenak FA, Brent RL, McCullough LB. The professional responsibility model of obstetric ethics: avoiding the perils of clashing rights. Am J Obstet 2011;205:315. e1-5.

21 Serour GI. Medical and socio-cultural aspects of infertility in the Middle East. Hum Reprod ESHRE Monographs 2008;(1):34-41.

22 Serour GI, Dickens BM. Assisted reproduction developments in the Islamic world. Int J Gynaecol Obstet 2001;74:187-93.

23 Nygren KG, Sullivan E, Zegers-Hochschild F, et al. International Committee for Monitoring Assisted Reproductive Technology (ICMART) world report: assisted reproductive technology 2003. Fertil Steril 2011;95(7):2209-22, 2222.e1-17.

24 Serour Gl. Islamic perspectives in human reproduction. Reprod Biomed Online 2008;17(Suppl 3):34-8.

25 Dickens BM, Serour GI, Cook RJ, et al. Sex selection: treating different cases differently. Int J Gynaecol Obstet 2005;90:171-7.

26 The International Federation of Gynecology and Obstetrics (FIGO). Resolution on 'Sex Selection for Non-medical purposes'. Nov 2006. http://www.figo.org/sites/ default/files/uploads/OurWork/2006\%20Resolution\%20for\%20Sex\%20Selection\% 20for\%20Non-Medical\%20Purposes.pdf

27 Serour GI. Religious perspectives of ethical issues in ART. Contemporary ethical dilemmas. In: Shinfield F, Sureau C, eds. Assisted reproduction. UK: Informa Health Care, 2006:99-114.

28 Holy Quran, Surat Al Bakara 2:233.

29 Margaria A, Sheldon S. Parenting post IVF: is age not so relevant after all? Reprod Biomed Online 2014;29:10-3.

30 FIGO Committee for the Ethical Aspects of Human Reproduction and Women's Health. Ethical guidelines on conscientious objection. Reprod Health Matters 2006:14(27):148-9.

31 Protecting our public health workers. Nat Rev Microbiol 2013;11:67.

32 Polio Eradication Initiative: Jeddah Declaration. Geneva: World Health Organization, 2014. http://www.emro.who.int/polio/information-resources/jeddah-declaration.html 